\title{
Is Bandung Panic Button Considered Effective During the COVID-19 Pandemic?
}

\author{
Wanda Viola Widiani*, Alfina Damayanti, Annisa Nur Syifa, Azzahra Salsabila Puspitasari, Meliana Intani, Nita \\ Nurliawati, Rofi Ramadhona Iyoega \\ Politeknik STIA-LAN Bandung \\ Bandung, Indonesia \\ *wandaviolaw@gmail.com
}

\begin{abstract}
Technological innovation is a solution to problems that occur in response to current developments. All aspects of life are inseparable from technology and of course make the job easier. Likewise, with fields managed by the government, based on Law Number 25 of 2009 concerning Public Services, an innovation must be carried out. Based on the Republic of Indonesia Government Regulation Number 38 of 2017, Bandung City created an innovation regarding public services in the security sector by creating a Panic Button which is managed by Bandung Command Center. There are many precarious situations that occur around us, such as fire, domestic violence, theft, extortion, and the others. This can be prevented by making effectiveness of the Panic Button which functions as an emergency liaison device created in the Bandung City to solve security problems. Moreover, during the pandemic COVID-19, various things must be adapted to suit the needs of people. Therefore, a qualitative approach is implemented in this paper through a survey conducted to 100 citizen measure the effectiveness of Bandung Panic Button during the time of pandemic COVID19.
\end{abstract}

Keywords-effectiveness, public services, panic button, pandemic

\section{INTRODUCTION}

Indonesia is a constitutional state that guarantees human rights to obtain security, a decent life, protection, freedom, and so on. The freedom and safety of a person in Indonesia is still far from expectations.

Along with technological developments, public services have conventionally shifted with the emergency of various complaint channels and innovations provided by service providers. Starting from the application for the provision of complaint SMS and WhatsApp numbers, integrated citizen forums on the provincial government or district government websites, even digital service and complaint applications that have been regulated in Law No. 30 of 2014 concerning Guidelines for public service innovation (UU No. 30 Tahun 2014 tentang Inovasi Pelayanan Publik).

Through the smart city system, Bandung City already has software for first handling when a crime occurs and as a means of public complaint, namely the Bandung Panic Button. This application is operated by the Bandung Command Center (BCC).

This application is a centralized and integrated security solution, where people who are in an emergency condition can send emergency messages to the Bandung Command Center. The Bandung City Government has strengthened its synergy with the police to work together to operate this application.

In general, the Panic Button application is classified as easy to use on Android-based smartphones, in which there are various interesting features or applications, such as:

- There are quite clear instructions regarding the use of the Panic button, such as the obligation to activate GPS, tap 3 times if in an emergency, and the police will come soon, and when the reporter is safe enough tap $3 \mathrm{x}$.

- The panic button application also provides up to date information about various events, grand performances, and news that will be held around Bandung.

- The Panic button application also provides information on public services around Bandung which include: hospitals, bus stops, police stations, sub-district offices, workshops, fire departments, ATMs, and so on.

- The most important feature in this application is to provide Emergency Call to make it easier for users to contact emergency number services such as Ambulance, Fire, and Police.

- There is transportation information, so users can find out the route that Damri and public transportation in Bandung will take.

Bandung Panic Button which was launched by the former mayor of Bandung in 2015, the system in this application has not been running optimally and has not been effectively used by the people of Bandung. In fact, this application is claimed by the Bandung City Government to be a solution for citizens who are pressed for emergencies. So, people of Bandung leave this application and switch to another emergency line such as 112. 


\section{LITERATURE REVIEW}

\section{A. Effectiveness}

Effectiveness can be used as a reference to compare the process carried out with the results that have been achieved. So that determining a program to be effective requires measurements. Effectiveness according to Mardiasmo [1] is a measure of the success or failure of achieving an organization's goals in achieving its goals. When an organization achieves its goals, the organization has been running effectively.

Meanwhile, according to Pekei [2] who argues that effectiveness is the relationship between output and goals or is said to be a measure of how far the output level. Effectiveness is also related to the degree of success of an operation in the public sector so that an activity is to be effective, if the activity has a major influence on the ability of service providers.

The concept of effectiveness shows the success or achievement of what is desired. Effectiveness is also a situation where the capabilities of a system can match the user's wishes. One of the things that cannot be separated from the effectiveness is in the service sector. The effectiveness of service is said to be successful if the government in this case as a service provider, is able to provide a service that is in accordance with the needs of the community to achieve the goal of a prosperous society.

\section{B. The Dimensions of Effectiveness}

According to Eipsten [3] states that there are four dimensions in measuring effectiveness, namely:

- Measures of community conditions, which is a measurement of the condition of service users in general so that they can see the needs of service users for services that are measured against this condition can become a standard in the services provided. This means that the services provided must be in accordance with the standards made based on the conditions of the community.

- Measures of service accomplishments, this measurement is a direct measurement of a specific service. So that the service provider organization can calculate the results of services performed in the short term and find out what is needed when the service is running. This measurement is measured through several things, including the demand for the service and how responsive the service provider organization is in providing services.

- Measures of citizen or client satisfaction and perception, where measurements are made by showing satisfaction with public services and perceptions of the condition of service users as part of society. Service user satisfaction is a measurement that can be used to this measure.

- Measures of the unintended adverse impact, this measure of effectiveness is a measurement by looking at other negative impacts that may arise if the need for the service cannot be served or cannot be accommodated by the service system in that place. This aims to see whether a service can have a negative impact that is not desirable even though the service tries to meet the needs of service users.

\section{Public Service}

Public service is a process of serving or providing all public needs. Government as a service provider to the people to meet people's needs so as to create welfare for the people. The government must be able to meet the needs of the public from all sectors ranging from matters of education, health, security and so on.

\section{Public Service Innovations}

Services provided to the people must be effective and efficient so that it makes it easier for the people. In providing services, it must also comply with established standards and provide maximum service. Therefore, to provide maximum service, one of them is there must be an effort to improve services.

To improve public services since 2014, the Ministry of Administrative and Bureaucratic Reform (MENPAN RB) has implemented a policy on public service innovation. Public service innovation is needed to improve quality. It takes new creative ideas, besides innovation is very important in order to answer the challenges of globalization and the development of advances in information technology.

\section{METHODOLOGY}

This research uses qualitative analysis through an interactive strategy with a case study approach based on oral, written analysis and documentation using online media. The analysis used in this research is to analyze the results of interviews, observations, websites and articles related to the Effective Bandung Panic Button Application Service. Furthermore, from this study it can be seen the usefulness of the Panic Button, how many users of this application, user satisfaction, and whether the application has been effective in handling emergencies. This research uses online media and official websites to analyze the reality of community involvement in using the Bandung Panic Button application, in order to support stakeholder partnership efforts in sending emergency messages and implementing digital technology.

The results collected are then analyzed through graphs to calculate respondents from the Bandung application service Panic Button. Using a qualitative analysis method is the right choice to describe the process of public services provided by the Bandung Command Center (BCC) through the Bandung Panic Button application, so that the results can be studied further to identify weaknesses and strengths and find efforts to improve them. This research performs data collection, data analysis, data interpretation, and ends with conclusions and recommendations based on data analysis. 


\section{ANALYSIS}

After we conducted the Bandung Panic Button Service Community Survey to 156 respondents, interviews with service officers at BCC, our observations and articles were able to analyze in relation to the effectiveness dimensions of Eipsten:

- Based on the survey results, 79\% of the public do not know about the Bandung Panic Button service, 20\% of the people know and $1 \%$ are in doubt (Figure 1).

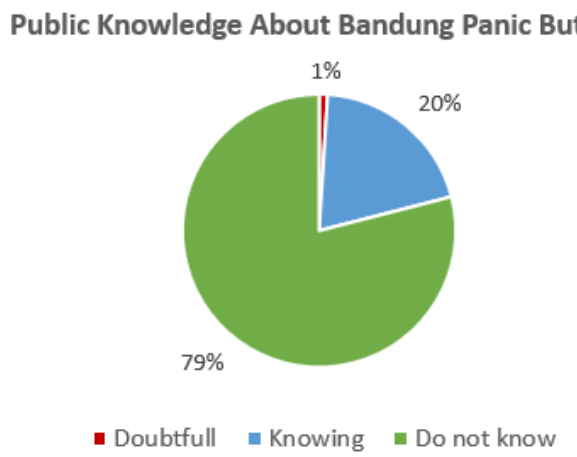

Fig. 1. Percentage of public knowledge about Bandung Panic Button.

- Like with the results of our interviews with BCC officers that the socialization of the Bandung Panic Button has not been as intense as the 112 service so that people use more of the 112 service compared to the Bandung Panic Button itself. Apart from that, we also found that the government often launches a program but it is only excited at the beginning. Like what happened to the Bandung Panic Button, moreover, this service is renting to a third party so that BCC pays a rent each year to pay for licenses and application maintenance costs.

- Compared with the 112 service which is easy to use because users only need to make calls and free calls and even do not use a phone card, it can be used, while the Bandung Panic Button must install an application and in use it requires a data package (quota) and activates GPS. The Bandung Panic Button service can only be accessed within the city of Bandung. But the advantage of the Panic Button is that it is more practical in sending the user's location when in an emergency where when the user sends an emergency signal the coordinates are immediately conveyed accurately and help can be immediately sent.
- Then the longer the use of the Bandung Panic Button decreased in December 2018, there were only 11 incoming calls consisting of 11 Testing Calls and 4 Valid Calls. In 2019 there were 111 incoming calls consisting of 23 Testing Calls and 88 Valid Calls. And in 2020 there are 25 incoming calls consisting of 24 Testing Calls and 1 Valid Call.

- Then if we look at this pandemic era, actually this service will be very effective for the community because in this pandemic era, emergencies are easier to occur, but as previously explained, this service has not been integrated nationally, such as 112 services.

\section{CONCLUSION}

Therefore, we can conclude that based on the results of our analysis based on the results of the survey conducted, this service has not been able to be said to be effective because it has not met the dimensions of service effectiveness where a public service should be said to be effective if the service is in accordance with the needs of the community. However, in this case, many people are not even aware of this service.

\section{RECCOMENDATION}

- Promote the panic button application in Bandung City even more intensively.

- Make a unique name so that it is easy to find and remember when needed.

- Making this application the default application by collaboration with related parties such as Google

- Innovating this application, such as making 3 red emergency buttons for hospitals, blue for fire engines, and yellow for the police

- Making this panic button easier to operate by all people both young and old people.

\section{REFERENCES}

[1] Mardiasmo, Perpajakan Edisi Terbaru, Yogyakarta: Andi, 2017.

[2] B. Pekei, Konsep dan Analisis Efektivitas Pengelolaan Keuangan Daerah di Era Ekonomi, Jakarta: Taushia, 2016.

[3] M.R. Streers, Efektivitas Organisasi (Kaidah Perilaku), Jakarta: Penerbit Erlangga, 1985 